Denysov S. F.,

Doctor of Sciences (Law), Professor, Head of the Department Criminal, Criminal and Executive Law and Criminology, Academy of the State Penitentiary Service, Chernihiv, Ukraine;

Puzyrevskyi M. V.,

Postgraduate Student of the Department of Criminal, Criminal and Executive Law and Criminology,

Academy of the State Penitentiary Service, Chernihiv, Ukraine

\title{
L. YE. VLADYMYROV'S DOCTRINE AS A BASIS FOR DEVELOPMENT OF CRIMINAL LAW THEORY ON THE TERRITORY OF UKRAINE
}

Vladymyrov's L. Ye. scientific activity was analyzed in the article. The main factors that contributed to the emergence of his scientific priorities were identified. The scientist's fundamental papers in the formation of his scientific outlook were described.

It is proving that the multifaceted scientific potential of L. Ye. Vladymirov played a decisive role in the development of the doctrinal provisions of the science of criminal law in the territory of Ukraine. The scientist prepared a number of fundamental scientific works, in particular, "Textbook of Criminal Law. General Part" (1889), "Criminal lawmaker as an educator of the people" (1903, 1908), "Course of criminal law. Part one. Fundamentals of the Current Criminal Law" (1908), etc.

So, the scientific and pedagogical contribution of Professor L. Ye. Vladymirov to the establishment and development of native scientific criminal and criminological school as well as his biography are considered. A brief characteristic of his scientific papers is given. The scientific and theoretical foundation created by professor are presenting. The uniqueness of the figure of L. Ye. Vladymirov lies not only in his fundamental knowledge, which has been reproduce in relevant scientific or scientificjournalistic works, or in combination with his scientific, public and state activities. A special place in the figure of a scientist is due to the value of his works for the formation and development of the Kharkiv and Moscow schools of criminal law.

Through the prism of the principle of history, it became possible for us to become aware of the reality of the day. It is arguing that his works have not lost their relevance on development of native theories of criminal law and criminology today, after almost a centuries since their publication.

Key words: Vladymirov Leonid Evstafievich, doctrine, scientific activity, criminal law.

Target setting. Today, at the time of the development of Ukrainian statehood, when issues of a national idea, national history become particularly relevant, the appeal to the contribution of those scientists who laid the foundations for domestic legal science is especially important. It should be emphasized that it is precisely during the devel- 
opment of a modern legal state that the issues of the continuity of legal provisions in science and in legislative practice is of particular importance. Therefore, the studying of the history of certain criminal and legal views, concepts, and ideas on time is not only possible, but necessary as well. Thus, the very studying of the national history of Criminal Law can serve as a basis for improving doctrinal legal thinking, national criminal legislation and practice of its application.

There is no doubt that the most important step in the justification of jurisprudence ideas is the end of the 19th and the beginning of the 20th centuries, characterized by the rapid development of socially meaningful views in general, and in the field of Criminal Law in particular. In this case, it is absolutely justified to mention the functioning of the Department of Criminal Law and Criminal Justice System and Legal Proceedings which the name of Vladymyrov Leonid Yevstakhiiovych is directly associated with at Law Faculty of Kharkiv Imperial University known at the territory of the Russian Empire and outside it.

Actual scientific researches and issues analysis. It is unjustified to state that L. Ye. Vladymyrov's scientific heritage was still not the subject of scientific research. However, according to a detailed analysis of papers devoted to the scientific contribution of the scientist, there is still no comprehensive study that would have been exhausted by L. Ye. Vladymyrov's contribution in the formation and development of the doctrine of Criminal Law at the territory of Ukraine.

Thus, a few works of the late 19th and early 20th centuries and of modern native scholars, such as: D.I. Bahalei and M.P. Chuynskyi [1], M.I. Bazhanov [2], P.S. Berzin [3], M.I. Veselovskyi [4], M.M. Kovalevskyi [5], Yu.A. Ponomarenko and O.I. Kharytonova [6], D.S. Ptashchenko and V.I. Ttiutiuhin [7], M.V. Sirotkina [8], P.L. Fris [9] were devoted to scholar's scientific achievements and his life path. It is an overview of papers devoted to the study of L. Ye. Vladymyrov's scientific heritage, proves the undeniable relevance of such research today. An important, in our opinion, is an analysis of scholar's biography with a gradual study of his progressive scientific works, which led to the formation of his scientific worldview, making a fundamental influence on the development of the domestic doctrine of Criminal Law. 
Purpose setting. The article presents an attempt to analyze the views of L. E. Vladimirov, who determined the further development of the modern doctrine of criminal law at the territory of Ukraine.

The statement of basic materials of the research. One of the most prominent representatives of the national (Kharkov) classical school of Criminal Law, Honored Professor, Doctor of Criminal Law, the author of manuals on protection in criminal cases, criminal psychology, as well as one of the first domestic textbooks on the General Part of Criminal Law, Vladymyrov Leonid (Lytman) Yevstakhiiovych was born on January 30, [February 12 - S.D.; M.P.] 1844 in Poltava region. At the same time, well-known specialists of that time on the history of state and law M.I. Veselovskyi and M.M. Kovalevskyi, in their studies, indicate the year of the birth of the scientist as 1845 [4, p. 629; 5, p. 908]. He studied at the Kharkiv Imperial University (now it is Yaroslav Mudryi National Law University). As V.I. Tiutiuhin and D.S. Ptashchenko [7] emphasized in their article, L. Ye. Vladymyrov already his first scientific paper "... in 1866, gave pro venia legendi $[$ for defense in order to obtain the right to teach $-\boldsymbol{S}$. D.; M. P. - the thesis "Theory of evidence" ... "[7, p. 95].

However, inevitably interesting in our opinion, as M.P. Chubynskyi and D.I. Bahalei noted in their research [1], is the fact that the first "... Ph.D. thesis was called: "Experiments on Criminal Law. About bad attempts". Taking into account that Leonid Vladymyrov followed a Jewish religion, the Faculty of Law decided to send a preliminary request for permission to the Minister of Education Delianov I. D. The latter, in turn, wished to not allow a citizen of Jewish origin to teach the legal, political and historical sciences, which was the main based on Christian faith. In September 1866, Leonid Vladymyrov presented his thesis pro venia legendi "The main features of the theory of evidence under the premise of modern science". The thesis was submitted for consideration to Professor O.I. Paliumbetskyi ..." [1, p. 78].

It should be noted that the opponents in defense of L. Ye. Vladymyrov's thesis "The main features of the theory of evidence under the premise of modern science" in order to get the title of PrivateAssociate Professor at the Department of Criminal Law Professor O.I. Paliumbetskyi and Associate Professor A.M. Stoianov were ap- 
pointed. Public defense took place on December 4 [December 17 S.D.; M.P.] in 1866 and was considered to be satisfactory [1, p. 86]. After graduating from university and obtaining permission to teach lectures, since February 1867 Leonid Yevstakhiiovych worked as a private Assistant Professor and taught lectures at the Kharkiv Imperial University.

February 20, [March 5 - S.D.; M.P.] 1870 he defended his Master's (Ph.D.) thesis "On the Importance of Doctors-Experts in Criminal Proceedings" (opponents - Professor O.I. Paliumbetskyi and Professor D. I. Kachenovskyi) [1, p. 92].

January 31 [February 13 - S.D.; M.P.] 1871 L. Ye. Vladymyrov was appointed Associate Professor of the Department of Criminal Law and Criminal Justice System and Legal Proceedings [1, p. 225], where the latter taught the course "Laws on Prevention and Suppression of Crimes".

In 1873 he defended his doctoral thesis "Jury court. Conditions for court acting and the method of evidence developing" (opponents Professor O.I. Paliumbetskyi, Professor A.M. Stoianov and Associate Professor L.M. Zahurskyi) [1, p. 95]. It was on the basis of the latter that he was awarded a scientific degree in Criminal Law, and in March 1873 he was elected an Extraordinary Professor.

Already from July 24 [August 6-S.D.; M.P.] 1874 L. Ye. Vladymyrov was approved in the rank of Full Professor at the Department of Criminal Law and Criminal Justice System and Legal Proceedings of Faculty of Law of Kharkiv Imperial University. In 1892 he got the title of Honored Professor of the University, where he worked until September 20, [October 3 - S. D.; M. P.] 1893 [1, p. 225].

At the beginning of November, 1893 he moved to Moscow, where he became to be engaged in advocacy. At the same time, he continued research in the areas of Criminal Law, Criminal Procedure, Criminal Justice, Forensic Psychology and the General Theory of State and Law. In his papers he defended liberal-democratic ideas and principles of the judiciary and law, fully substantiated the theory of court evidence, deeply studied the nature and activities of the jury, the mechanism of the impact of criminal law on legal consciousness.

Vladymyrov L. Ye. died on September 8, 1917 in his Moscow apartment in a foreign country. 
Thus, in our opinion, it is indisputable that the scholar's scientific heritage is extremely valuable for domestic material criminal and legal doctrine. Yes, L. Ye. Vladymyrov (1844 (1845) - 1917) prepared a number of fundamental scientific papers, in particular concerning:

- Criminal Law: "Textbook of Russian Criminal Law. General Part" (1889) [10],"Criminal Legislator, as the educator of the nation" (1903, 1908 years) [11],"Criminal Law Course. Part One: Basis of Current Criminal Law" (1908) [12];

- Criminal Process and Legal Proceedings: " On the Importance of Doctors-Experts in Criminal Proceedings" (1869, 1870 years) [13], "Court of Jury: the conditions for operating the court of jury and the method of developing evidence" (1873) [14], "Criminal Defense Reform" (1886) [15],"Defensive Speeches and Public Lectures" (1892) [16], "The Doctrine of Criminal Evidence: Parts: General and Special" (1882, 1883, 1910 years) [17], "Advocatus miles. A Handbook for Criminal Defense" (1911) [18];

- Forensic Psychology: "Psychic features of criminals on the latest research" (1877) [19], "The law of evil" (1892) [20], "Psychological investigation in the criminal court" (1901) [21];

- General Theory of State and Law "Aleksey Stepanovich Khomiakov and his ethical and social doctrine" (1904) [22], "The meaning of the idea of law in the social life of mankind" (1904) [23], "Legal Creativity" (1905 p.) [24], "Textbook of Jurisprudence" (1911) [25].

Among other things, in our opinion, first of all deserves one of the first domestic textbooks on Criminal Law "Textbook of Russian Criminal Law. General Part" (Kharkiv, 1889) [10]. Yes, it is in this paper, all the major institutes of this branch of law were considered from the standpoint of that time by Professor of Kharkiv Imperial University L. Ye. Vladymyrov.

Defining Criminal Law, he pointed out that he had "... an order of the state authority, duly published, defining the features of the crime and the corresponding state punishment ..." [10, p. 22].

As P.L. Fris rightly claims in his monographic study: "... in the approach of L. Ye. Vladymyrov to understanding the essence of the crime the remnants of the forensic approach to the assessment of this institution revealed (where he came to the material Criminal Law from) ..." [9, p. 73]. 
In addition, in our opinion, Leonid Yevstakhiiovych owns the first domestic definition of intent and negligence as appropriate forms of guilt, which, in his opinion, is a "criminal will" [10, p. 83]. So, L. Ye. Vladymyrov considered the stages of committing a crime through the prism of "committing criminal will", while highlighting "naked intent (nuda cogitatio)", "preparing for a crime (delictum praepatum)", "attempt (conatus delinquendi)" and "committed crime (consummatum)" [10, p. 97-107].

While maintaining detailed analysis of the institution of complicity in crime, L. Ye. Vladymyrov defined it as "... the agreement of several persons to make in common the following or several unpredictable crimes ...". At the same time, he formulated and signs of complicity, which included: the existence of common intent and preliminary agreement on the commission of a crime; joining forces of accomplices; consistency in the commission of one or several (indefinite number) crimes [10, p. 108-109].

It should be emphasized that L. Ye. Vladymyrov became one of the first domestic criminologists who considered, however, somewhat limited, the problem of plurality of crimes, and although he did not directly call this institution, he stopped at the legal analysis of situations that we define today as a combination and repetition of crimes [10, p. 107].

It was developed by him and the institution of circumstances excluding criminal liability, which he defined as "legal justification" and which included the implementation of law; necessary defense, state of extreme necessity, victim's consent [10, p. 63-74].

Also, L. Ye. Vladymyrov did not miss the institute of criminal punishment. Concerning the latter, attention was paid to the fact that "... The highest purpose of criminal punishment is to develop a sense of responsibility for its actions as a particular person, a criminal, and the whole society. A person must understand from the very childhood that any of his/her actions will have certain consequences. If he/she has done a bad deed, he/she must feel some suffering. The idea of responsibility should become a sense of responsibility in order to be almost intuitive motive in people's behavior ..." [10, p. 7].

We consider it appropriate to support the scientific position of P.L. Fris, who claims that L. Ye. Vladymyrov's textbook "Textbook 
of Russian Criminal Law. General Part" undoubtedly became "the first Ukrainian textbook on the General Part of Criminal Law that summed up the ways of the criminal and legal policy of the Russian Empire in the 19th century and outlined the direction of its development in the future "[9, p. 74], in particular, at the territory of Ukraine.

However, in our opinion, another scientific paper of monographic nature on criminal and legal issues deserves no less attention in scholar's outstanding scientific contribution. It is "Criminal Legislator, as the educator of the nation" (Moscow, 1903) [11]. So, in his monographic study L. Ye. Vladymyrov described that the legislator, pursuing its special goals, should not ignore that "... criminal legislation is a powerful state means of education, and therefore should bear in mind the main objectives of moral education of the whole nation in general ..." [11, p. 81]. As the scientist rightly pointed out: "... the main tasks of moral education of the nation must be concentrated in the development of a sense of responsibility, a sense of compassion and the ability of honor (respect) ..." [11, p. 1-28]. As for the purposes of the implementation of criminal justice, the latter emphasizes the fact that "... the calling of criminal justice is to intimidate, justice, correct an offender and general moral upbringing of the nation ..." [11, p. 29-80].

Also interesting is the scholar's opinion that "... it is necessary to reduce, if possible, the number of different restrictions, violation of which is a long list of crimes and misdemeanors, especially those constituting contingent crimes, that is, not all crimes, and crimes that are such only because they are forbidden under the fear of punishment ... " [11, p. 49].

In addition, L. Ye. Vladymyrov insisted in the fact that "... fight against crime can't be proclaimed the aim of justice. In fact, it would be more convenient and successful to have a fight if the criminals were physically destroyed. But the state does not fight with sick and uneducated people. The state treats sick people, educates uneducated people, re-educates poorly-educated people..." [11, p. 82].

Conclusions of the research and prospects. Today it is possible to evaluate L. Ye. Vladymyrov's scientific activity in different ways: to uphold theoretical achievements in the Doctrine of Domestic Criminal Law, to indicate the methodological shortcomings of his papers, 
and so on. At the same time, none of the assessments will claim objectivity. Undeniable is that L. Ye. Vladymyrov's life path, marked by a constant search, an actualization of European ideas, tireless work ability, has not been properly investigated and evaluated. The scholar was one of the founders of the Doctrine of Classical Criminal Law in Ukraine, the most prominent representative of the national (Kharkiv) classical school of Criminal Law, author of manuals on Criminal Justice, methods of defense in Criminal Proceedings, Criminal (Judicial) Psychology, as well as one of the first domestic textbooks from the General Part of Criminal Law.

All of the foregoing suggests that, while studying the main institutes of the doctrine of crime, justice and punishment L. Ye. Vladymyrov was at the level of the advanced science of that time, and therefore, the prospect of future studies is further revealing of scholar's innovative fundamental views, their influence on the development of Ukrainian jurisprudence in general, and criminal and legal science in particular.

\section{References}

1. Bagaley, D. I., Chubinsky, M. P. (1908), The Faculty of Law of Kharkiv University for the first hundred years of its existence (1805-1905). Kharkiv: Typography "Printing Business".

2. Bazhanov, M. I. (1998), Volodymyrov Leonid Yevstakhiiovych. Legal Encyclopedia: in 6 t. T. 1: A-G. Kyiv: Ukrainian Encyclopedia. P. 509.

3. Berzin, P. S. (2016), "Kharkiv School of Criminal Law: General Characteristics of Development in 1804-1919 and Analysis of the Activities of Criminal Law Instructors at the Imperial Kharkiv University during 18041834" (Part I). Bulletin of the Criminal Law Association of Ukraine. No. 1 (6). P. 51-112.

4. Veselovskyi, N. I. (1892), Vladimirov Leonid Yevstafievich. Encyclopedic Dictionary. Volume 6a: Vinoslovie-Volan. St. Petersburg: Typo-Lithography by I. A. Efron. P. 629.

5. Kovalevsky, M. M. (1912), Vladimirov Leonid Yevstafievich. New Encyclopedic Dictionary. Volume 10: Völlner-The discipline is power. Saint-Petersburg: Typography of the Joint-Stock Company Brokhaus-Efron. P. 908.

6. Sirotkina, M. V. (2004), Volodymyrov Leonid Yevstakhovych. Anthology of Ukrainian legal thought. Volume 7: Criminal Law. Criminal process Kyiv: Law Book. P. 146-148. 
7. Ponomarenko, Yu. A. and Kharitonova, Ye. I. (2011), "Kharkiv School of Criminal Law". The Law of Ukraine. No. 9-10. P. 265-274.

8. Ptashchenko, D. S., Tiutiuhin, V. I. (2017), Vladymyrov Leonid Evstakhiiovych. The Great Ukrainian Law Encyclopedia: 20 volumes. Vol. 17: Criminal Law. Kharkiv: Law. P. 95-96.

9. Fris, P. L. (2005), Essay on the History of Criminal Law of Ukraine: Monograph. Kyiv: Atika.

10. Vladymirov, L. Ye. (1889), Textbook of Russian criminal law. The whole part. Kharkiv: Publishing of typographies of Kaplan and Biryukov, 1889.

11. Vladymirov, L. Ye. (1903), The criminal lawmaker, as a teacher of the people. Moscow: The Society of Printed Materials of A.A. Levenson.

12. Vladymirov, L. Ye. (1908), Course of Criminal Law. Part One: the basis of the current criminal law. Moscow: Society of I.D. Sytin.

13. Vladymirov, L. Ye . (1870), On the significance of the expert doctors in the criminal proceedings. Kharkiv: University typography.

14. Vladymirov, L. Ye. (1873), The jury: the condition of the practice of the jury and the method of developing evidence. Kharkiv: University typography.

15. Vladymirov, L. Ye. (1886), Reform of criminal defense. Kharkiv: Publishing of typographies of Kaplan and Biryukov.

16. Vladymirov, L. Ye. (1892), Protective speeches and public lectures. Moscow: The Society of Fine Arts A. A. Levenson.

17. Vladymirov, L. Ye. (1910), Uchenie about criminal evidence: Parts: general and special. St. Petersburg: The publication of the bookstore "Laws".

18. Vladymirov, L. Ye. (1911), Advocatus miles. Posobiye for criminal defense. St. Petersburg: The publication of the legal bookstore I.I. Zubkov.

19. Vladymirov, L. Ye. (1877), Psychic features of criminals on the latest inquest. Kharkiv: University typography.

20. Vladymirov, L. Ye. (1892), The law of evil. Kharkiv: Typography of Adolf Darre.

21. Vladymirov, L. Ye. (1901), Psychological investigation in the criminal court. Moscow: The Society of Fine Arts A.A. Levenson.

22. Vladymirov, L. Ye. (1904), Aleksey Stepanovich Khomyakov and his ethical and social sciences. Moscow: The Society of Printed Materials A. A. Levenson.

23. Vladymirov, L. Ye. (1904), Significance of the idea of law in the social life of mankind: introductory lecture. Yekaterinoslav: Typography of the Gubernskogo Zemstva.

24. Vladymirov, L. Ye. (1905), Legal creativity: introductory lecture. Moscow: The Society of Printed Materials A. A. Levenson. 
25. Vladymirov, L. Ye. (1911), Textbook of jurisprudence. St. Petersburg: Publishing of the Legal Bookstore I. I. Zubkov.

Денисов С. Ф., Пузиревський М. В.

\section{ВЧЕННЯ Л. Є. ВЛАДИМИРОВА ЯК ФУНДАМЕНТ РОЗВИТКУ ДОКТРИНИ КРИМІНАЛЬНОГО ПРАВА НА ТЕРЕНАХ УКРАЇНИ}

У статті проаналізовано наукову діяльність Л.С. Владимирова. Виявлено головні чинники, які сприяли зародженню його наукових пріоритетів. Схарактеризовано фундаментальні праці вченого у формуванні його наукового світогляду.

Доведено, щзо багатоаспектний науковий доробок Л. С. Владимирова відіграв вирішальну роль на розвиток доктринальних положень кримінальноправової науки на теренах Украӥни.

У статті розглянуто біографію, докладно показано науковий $і$ педагогічний внесок професора Л.С. Владимирова у становлення й розвиток вітчизняної наукової кримінальної та кримінологічної школи. Наведено коротку характеристику його наукових працьь.

Ключові слова: Владимиров Леонід Свстахійович, вчення, наукова діяльність, кримінальне право. 